\title{
One-person enterprises and the phenomenon of hybrid self-employment: evidence from an empirical study
}

\author{
Dieter Bögenhold ${ }^{1}$ Andrea Klinglmair ${ }^{2}$
}

Published online: 8 April 2016

(C) The Author(s) 2016. This article is published with open access at Springerlink.com

\begin{abstract}
The complex interaction of technological development and socio-demographic change has accelerated a structural change in the economy, resulting in a changing working environment and new forms of employment. In the field of selfemployment, an emerging trend towards one-person enterprises can be observed, which already represent more than $50 \%$ of all Austrian companies. Based on a representative sample of 626 one-person enterprises in Carinthia, one of the federal countries in Austria, we found out that these micro enterprises are mainly driven by motives like self-realization or working without hierarchies. However, their emergence is also partly due to a lack of opportunities in the (dependent) labour market. Additionally, we found evidence for the phenomenon of hybrid self-employment, meaning that a significant part of the one-person enterprises (nearly 20\%) is additionally engaged in dependent work. The primary aim of this paper was to identify factors influencing these hybrid forms of employment status between dependent work and self-employment. Based on a binary Logit model, we found evidence that the hybrid employment status is mainly determined by age, the educational level, the situation in which the one-person enterprise was founded, the duration of the enterprise as well as the motives for being self-employed.
\end{abstract}

Keywords Micro enterprises · Self-employment · Entrepreneurship · Labour market · Online-survey · Logit model

Andrea Klinglmair

a.klinglmair@ihsk.at

Dieter Bögenhold

Dieter.Boegenhold@aau.at

1 Department of Sociology, Alpen-Adria-University Klagenfurt, Universitätsstraße 65-67, 9020 Klagenfurt am Wörthersee, Austria

2 Institute for Advanced Studies Carinthia, Alter Platz 10, 9020 Klagenfurt am Wörthersee, Austria 
JEL Classification $\mathrm{C} 13 \cdot \mathrm{C} 83 \cdot \mathrm{J} 49 \cdot \mathrm{M} 13 \cdot \mathrm{M} 20$

\section{Introduction}

In combination with ideas about new regional economies and new information and communication technologies, entrepreneurship serves as a universal key, which provides in-itself fruitful paths into the future (Audretsch 2007). In this understanding, entrepreneurship as an institution serves to be a kind of "pivot on which everything turns" (Schumpeter 1954), which was held to be true in the twentieth century, but looks to be the same in the twenty-first century as well. However, entrepreneurship seems to be poorly defined and the acknowledgement of entrepreneurship does not consider the enormous heterogeneity of the category. If we employ the labour market category of self-employment as a proxy for entrepreneurship, which may occasionally be questioned but which most closely resembles actual practice, it becomes evident that in many countries the majority of entrepreneurs belongs to the category of micro firms, which effectively exist as one(wo)man companies. Many of their number are not even registered in the yellow pages or have their own premises or a sign above the door.

While Schumpeter (1963) portrayed the entrepreneur as a "captain of industry", the actors of our study do not match this image. They do not govern industrial empires, but they work on their own, without additional employees. In some way, their current status and their biographies display a somewhat hybrid nature, positioned between wage or salary dependency and the freedom of entrepreneurs in their stereotype (Folta et al. 2010). "Die-hard entrepreneurs" (Burke et al. 2005) are those actors, who are portrayed in public discourse and also in economics as those agents, who are dynamic, willing to expand and to engage in risk-taking. Conversely, those self-employed actors who do not meet with this image, but who are the majority of people in terms of self-employment numbers, seem to be rather neglected.

\section{Entrepreneurship, self-employment and the labour market}

According to the Labour Force Survey (Eurostat-Database 2015a), $58.0 \%$ (data for the year 2014) of all self-employed people in Austria work without additional employees in their firms. Looking at the figures for the broader European level (EU28 ), the ratio of micro-firms is even higher. Here, $71.5 \%$ of all individuals in selfemployment work on their own, without further hired labour. "Die-hard entrepreneurs" (Burke et al. 2005) look different; they are thought of as captains of companies with different hierarchies, who operate these firms with a large crew of employees. Data for the areas of the chambers of commerce in Austria ("Wirtschaftskammern") indicate that approximately $58 \%$ of their members belong to the category of one-(wo)man companies (WKO 2015; Statistik Austria $2013 \mathrm{~b}$ ) and additionally, more than half of the newly established firms in Austria are one-person start-ups (Statistik Austria 2013c). 
Commonly, we speak about entrepreneurs, if these people are working independently on their own, regardless of whether their economic activities are small or big. However, the question if entrepreneurship is a transitional economic function or if it is a specific labour market category (e.g. the group of self-employed people), has not really been decided and, in academics and in policy, it leaves the decision open to pure arbitrariness. Relevant literature is full of competing definitions of entrepreneurship, "which differ along a number of dimensions, i.e. whether entrepreneurship should be defined in terms of dispositions, behaviour, or outcomes; whether it belongs in the economic-commercial domain or can be exercised also in not-for-profit contexts; whether it belongs only in small and/or owner-managed firms or in any organizational context, and whether purpose, growth, risk, innovation or success are necessary criteria for something to qualify as entrepreneurship" (Davidsson 2003, 316).

A wide variety of different entrepreneurial categories and related discussion about them exist (Bögenhold 2004; Shane and Venkataraman 2000); e.g. among these are female entrepreneurs, migrant entrepreneurs, free-lancer entrepreneurs, academic entrepreneurs, micro-entrepreneurs, agricultural entrepreneurs like farmers and fishermen, team entrepreneurs, elder entrepreneurship performed by actors after their retirement, or social entrepreneurs, so that the social and economic divergencies are sometimes greater than the common attributes they share. To be more precise, we decide to avoid the term entrepreneurship in our discussion and to refer to the category of self-employment which contains winners and losers in the labour market, with high degrees of uncertainty regarding the future due to permanently changing market situations for goods and services on offer.

In contrast to stereotypical assumptions, the phenomenon of self-employment looks entirely different when it is studied as a phenomenon embedded in the labour markets and specific occupational contexts, applications and sectors (see e.g. Welter 2011). Some types of small businesspersons and independent professionals do not show ambition for growth and they are sometimes very close to low income ranges, occasionally to poverty (Kautonen et al. 2010; Shane 2008). Empirical studies on diverse groups of self-employed individuals in larger societal and labour market contexts may produce alternative pictures (see Blackburn and Kovalainen 2008). A narrower and more realistic view shows that there are diverse agents under the flag of self-employment, who are usually not regarded as "die-hard" or "core" self-employed actors. In their study on Finnish freelancers, Bögenhold et al. (2014) discussed the blurred boundaries of independent and dependent work. Even between different groups of freelancers, different social rationalities were visible, e.g. journalists, translators and artists differed considerably regarding their strategies to move into or to leave the status of self-employment.

Nevertheless, we increasingly find ourselves in a world, which mirrors a puzzle of labour market patterns and biographical careers in which the clinical dichotomy between wage- or labour-dependent work on the one side and self-employed activities on the other side is muddied. This occurs because hybrid forms of combinations arise, where people have more than one job at one time or along the biographical axis of individual careers so that we observe patterns of multiplicity 
and parallelisms. According to these circumstances, the black and white dichotomy of being dependent or self-employed seems to have become a pattern which loses practical relevance in many cases, because people are not either/or but both.

Markets and the societies in which these markets are embedded are always in transition; they come up, they go down, and they change. Consequently, competition processes must also be analysed and understood as ongoing social processes, which are involved in social structures and which are permanently in processes of reorganization, being framed by institutions with specific coordinates of time and space. In general, a coincidence between the emergence of newborn firms, the general macroeconomic business climate, and a wide range of institutional factors is noted (see Davidsson 1995; Audretsch 1995; Acs and Karlsson 2002), and fostering of competition and new firm formation goes along with increased business entries (Wennekers et al. 2010; Mueller and Thomas 2000; Thurik and Dejardin 2012). Furthermore, due to secular changes in life-styles and values, an increasing number of free-lancers is emerging (not only but often in relation to the growing ITsector), who just want to work on their own without being involved in hierarchies (Hytti 2005). The ongoing trend towards an economy and society portrayed and governed by services (Castells 1998) proves to be not only a breeding ground for new occupations and jobs, but also for new opportunities to build upon freelanced activities and entrepreneurship.

Previous studies on the topic of micro self-employment (see for instance Bögenhold and Fachinger 2007, 2011; Leicht 2000) were mostly concerned with an investigation of available public census data. Other studies have dealt more explicitly with the blurred boundaries between wage dependent work and selfemployment (Burke et al. 2005; Folta et al. 2010; Noseleit 2014; Raffiee and Fen 2014). Burke et al. (2005) specified several factors determining variations of choices for entrepreneurship, among them age, gender and education. Folta et al. (2010) stressed the hybrid nature of people in transitory phases being dependent workers and self-employed people.

Our study is based upon a genuine empirical survey asking about the rationality of small self-employed actors without additional employees (including many selfemployed freelancers). What are their economic and social rationalities, and how can they be interpreted in terms of the recent popular discussion about entrepreneurship; is their emergence due to missing chances in the labour market for their stakeholders and/or do they reflect new interesting patterns to interpret and to realize participation in business life? The primary aims of the study are to learn, in a first step, something about the division of one-person enterprises. Questions include: in which branches are the economic and social actors concentrated; what about the relation to customers and clients; how much do they earn; how do they derive a living from the economic activity in self-employment? All these aspects contribute to an appropriate understanding of the landscape of one-(wo)man enterprises, while a further research inquiry goes deeper, asking for the socioeconomic logics of these small companies. The assumption is that the sample includes companies, which are driven by the need or necessity to realize some kind of economic income (instead of being unemployed), and those, which are also or 
almost entirely driven by "non-economic motives", such as self-realization or working without hierarchies (Mandl et al. 2007).

The primary focus of the empirical research is concerned with discussing the overlapping of the (formal) labour market and labour market employees on the one hand, with self-employment on the other hand. The results aim to highlight the idea of hybridization of social, economic and labour market categories through the use of own empirical data and econometric analysis.

\section{The role of one-person enterprises in Austria}

For the past several years, increasing numbers in self-employment have been registered. In Austria, the number increased from 405,700 in 2004 to 440,500 in 2014 , which is a rise of $8.6 \%$; at the same time the number of employees increased by $12.7 \%$. Controlled for gender, female self-employment increased even more than male self-employment, with $18.8 \%$ compared to $3.6 \%$ over the same time period. Compared to the numbers for the average of the European countries (EU 28 ), the ratio of self-employment among the total labour force is comparatively low in Austria. While the EU-28 countries have a share of nearly $14.4 \%$ of selfemployment, Austria has just $10.9 \%$ (data 2014). However, the ratio of selfemployment seems to have some permanence in its development.

Figure 1 also clearly shows that while self-employment seems to have considerable stability, if we take the ratios of self-employment as an indicator, in Europe as well as in Austria, the proportion of solo self-employment increases. Solo self-employment is the subcategory of self-employment defined as people being self-employed but not involving further employees in their economic activities. While in Europe (EU-28) the share of solo self-employment (among total selfemployment) has increased continuously since 2002 (from 69.0 to $71.5 \%$ in 2014), in Austria a similar increase has been taking place since 2007 (from 56.6 to $58.0 \%$ in 2014). In other words, if self-employment remains nearly constant over time and if the subcategory of solo self-employment increases, the nature of self-employment changes at the same time. Defining all self-employed activities as part of entrepreneurship, then entrepreneurship and entrepreneurial activities are

(a)

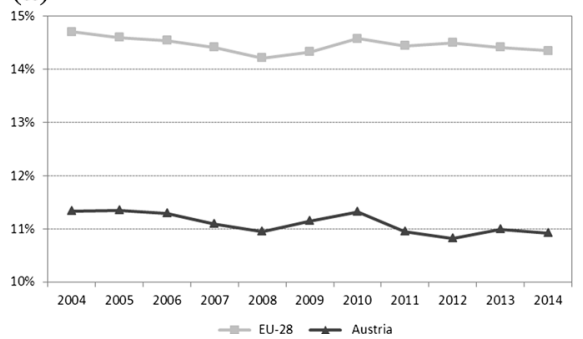

(b)

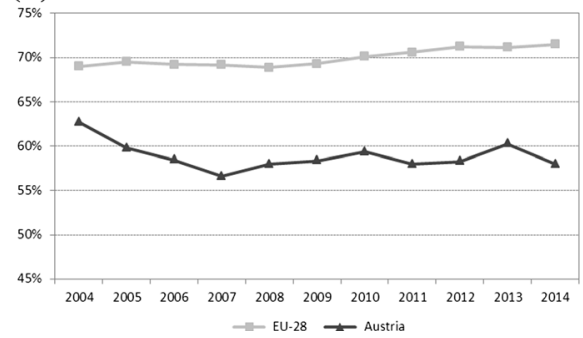

Fig. 1 Rate of self-employment (a) and the share of sole self-employment (b), 2004-2014 (EurostatDatabase 2015a, b; own calculations and depiction) 
increasingly carried out by one-(wo)man companies, which may be classified as micro-entrepreneurship.

Based on data provided by the Austrian Chamber of Commerce ("Wirtschaftskammer Österreich"), one can analyse the economic sectors in which solo selfemployment-considered as micro-self-employment—takes place. Figure 2 shows the ratios of solo self-employment for different economic sectors in Austria. In the areas of business and crafts, and in information and consulting, more than $60 \%$ of all (registered) firms are run by solo self-employed persons, while the economic sectors trade, industry, transport, tourism and leisure have shares between 30 and $50 \%$.

There is a "positive" line of interpretation, which says that those actors are the potential successful "bigger" businessmen of tomorrow. According to this interpretation, solo self-employment is the seed for future take-offs and this socioeconomic subcategory may bridge towards dynamics, economic growth and positive labour market effects. Conversely, the "negative" line of interpretation is guided by the idea that solo self-employment is close to precarious work as a deficient work of labour markets and industrial relations (Kalleberg 2011), and that solo self-employment signals a lack of secure dependent jobs in the regulated labour market. Corresponding with this interpretation, solo self-employed actors are pushed into their activities due to the existence of labour market frictions.

Increasingly, an-intermediating - third position has been entering the market for interpretations, suggesting that solo self-employment is by its nature partly also an emerging phenomenon, where, due to the shifting context of service sector related trends in economy and society (Gatterer and Kühmayer 2010, 3; Mandl et al. 2009, 215; Puchleitner 2014; Korunka et al. 2011, 446), people just want to survive on their own, since they do not want to work in hierarchies, and because they want to arrange their working duties to align with private and family related constraints and all this without explicit ambitions to grow and to wait for the first (or further) employees. All these competing interpretations are in charge of competing political interpretations and positions within the landscape of daily life politics. However,

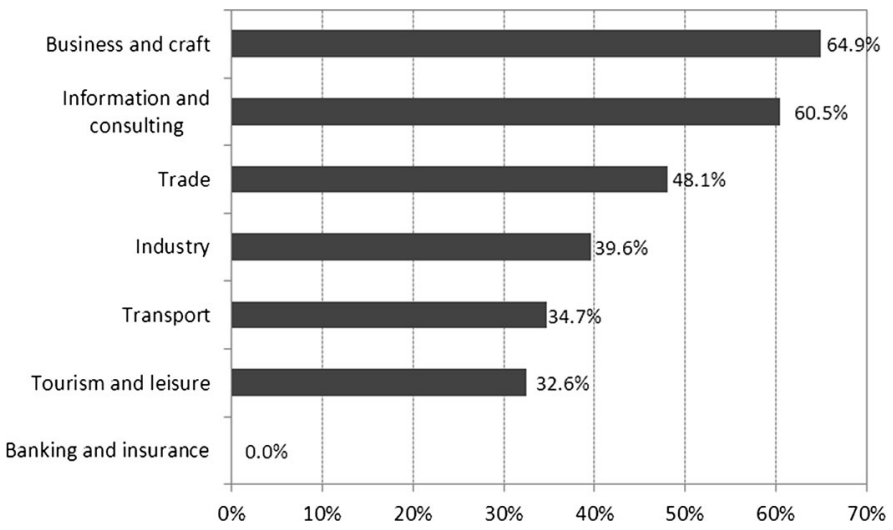

Fig. 2 Ratio of solo self-employment for economic sectors in Austria, 2014 (WKO 2015; own depiction) 
Table 1 Gross yearly income by primary source of income, Austria 2011 (Statistik Austria 2014, 235, 2016, 255)

\begin{tabular}{lll}
\hline Primary source of income & Median & Mean \\
\hline Employment & $€ 24,843$ & $€ 29,017$ \\
Self-employment & $€ 10,944$ & $€ 23,366$ \\
\hline
\end{tabular}

what is really needed are empirical data in order to see which interpretation comes closer to reality, if one does not wish to fall into traps of guesswork.

The hypothesis of the empirical study is that the empirical sample includes different groups, which are representative of the different interpretation categories, which include those who are driven by motives of self-realization (Bank Austria 2012, 12; Mandl et al. 2007, 45) and those who are pushed towards solo selfemployment due to missing chances on the labour market (Rosner and Krenn 2013). Looking at statistical figures for annual gross incomes of dependent employees and self-employed people shows that the incomes in self-employment are lower and that the indices for median and mean figures differ considerably in self-employment, which means that the volatility and the divergencies amongst self-employed incomes are very strong. Comparing the medians of incomes indicates that selfemployment incomes are less than half of the incomes of employees. These figures suggest that many incomes are close to poverty and/or are not sufficient to allow as single subsistence but must be combined with further sources of income (Table 1).

Moreover, the Gini-Coefficient-as a measure of inequality—shows that the gross incomes of dependent employees are distributed more equally (GiniCoefficient $=39.1 \%$ ) as compared to the group of self-employed where the Gini-Coefficient amounts to $56.6 \%$ (Statistik Austria 2013d, 112; Ehrenberg and Smith 2003, 500).

\section{The empirical survey}

As shown in the previous sections of this paper, factors like the technological development ("digital age"), the structural change on the labour market towards a service economy, changing social preferences, as well as economic crises, are leading to new life goals and new forms of jobs, triggering self-employment. Especially one-person enterprises play an important role in the Austrian business sector. But what are the economic and social rationalities of these micro enterprises, what are their motives for being self-employed? How satisfied are the one-person enterprises with their professional situation; what about their economic and financial situation and, finally, is their emergence due to missing chances in the labour market? In order to answer these questions, a comprehensive online survey has been implemented in cooperation with the Chamber of Commerce in Carinthia. The survey is based on a questionnaire containing 52 questions in total; this 


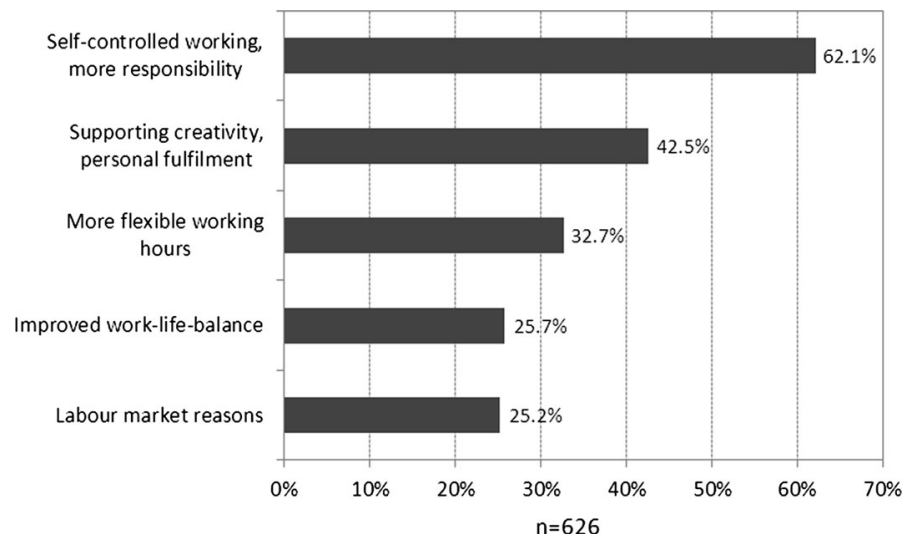

Fig. 3 Motives for self-employment (multiple answers; in \%)

questionnaire has been developed and tested in a process lasting several months and has finally been adapted for the online survey with the help of appropriate software (LimeSurvey). The contents of the questionnaire refer to the extent and motives of self-employment, client relations, success and satisfaction with self-employment, future prospects of the one-person enterprises, and socio-economic characteristics.

In February 2014, in total 9002 one-person enterprises were contacted by the Carinthian Chamber of Commerce and invited to participate in the online survey. The response rate was $7.0 \%$, resulting in a sample size of 626 one-person enterprises. The generated sample is representative with respect to the legal form (mainly individual companies), age (mean age in the sample and in the total population: 47 years) and gender, whereas males are slightly overrepresented in the sample compared to the basic population. Regarding the economic sector, oneperson enterprises from the information and consulting branch are considerably overrepresented (sample: $30.2 \%$, total population: $15.8 \%$ ). This result may be due to the higher affinity for technology of this group of micro enterprises and the associated familiarity with online surveys. Conversely, business and craft enterprises are represented less in the sample $(37.4 \%)$ than in the total population $(48.5 \%)$. Moreover, gender-related differences can be observed. While business and craft enterprises are mainly female (share of women: $51.1 \%$ ), the information and consulting sector is dominated by men (share of men: $73.5 \%$ ). Additionally, the information and consulting sector exhibits a high share of academics (46.6\%), while one-person enterprises in the remaining economic fields are significantly less educated.

\subsection{Motives and hybrid self-employment}

As indicated above, the empirical survey covers a wide range of issues related to self-employment as a one-person enterprise. The empirical results of this paper focus on the motives for being self-employed and the determinants of hybrid selfemployment. 
The main motives for self-employment are shown in Fig. 3. The most often-cited argument for being self-employed (62.1\% of the respondents) is the possibility of self-controlled working and the associated higher level of responsibility. In addition, $42.5 \%$ of the respondents think that self-employment represents the best way to develop the own creativity and achieve personal fulfilment. Finally, more flexible working hours and the associated improved work-life-balance rank among the major rationalities for setting up an own business. Beside these non-economic factors, economic motives play an increasingly important role for the decision to become self-employed. Hence, about one quarter (25.2\%) of the one-person enterprises decided to work as a one-person enterprise due to labour market reasons. ${ }^{1}$ Labour market reasons refer to the individual inability of finding dependent employment, the precarious labour market situation that requires self-employment, or the representation of self-employment as an alternative to or escape from unemployment. We found evidence that these one-person enterprises are more frequently unsatisfied with their professional situation, are less optimistic regarding their entrepreneurial future, earn less, and mainly belong to the age group $>45$ years (Bögenhold and Klinglmair 2014, 2015).

Another important result of the empirical study relates to hybrid self-employment. As shown in Fig. 4, slightly less than two-thirds $(63.6 \%)$ of the one-person enterprises are only self-employed and perform no additional activities. In contrast, about $9.6 \%$ of the respondents exercise a second self-employed activity; a further $18.5 \%$ have an additional dependent employment beside their business. The latter can be described as hybrid forms of self-employment because of the combination between independent and dependent employment.

First, this result begs the question whether the additional dependent employment represents a necessity-driven secondary job in order to survive economically, or whether the one-person enterprise represents a secondary source of income, i.e. a side-line business. A closer look at the empirical data reveals that half of the hybrid one-person enterprises are in full-time employment ( $36 \mathrm{~h}$ per week and more) beside their business activity. A further $26.7 \%$ perform a secondary part-time job with an extent of 20-35 h per week. The mean monthly net income from dependent employment amounts to $€ 1357$, while from their self-employed activity, the oneperson enterprises gain an average net income of $€ 608$, which is significantly lower compared to the income gained from wage-dependent employment. These results indicate that in cases of hybrid self-employment, the one-person enterprises rarely operate as a main business. In most of the cases, the self-employed activity rather represents a side-line business, meaning that the major source of income stems from dependent employment, while the one-person enterprise portrays only a secondary income.

Second, the empirical study aims to find out which factors influence whether a one-person enterprise holds an additional dependent employment or not. Is hybridity in self-employment determined by the socio-demographic background or does it depend on the professional environment or attitude of the one-person enterprise? In

\footnotetext{
1 Additionally, $16.9 \%$ of the respondents stated that they started their business activities as a one-person enterprise during or subsequent to a period of unemployment.
} 


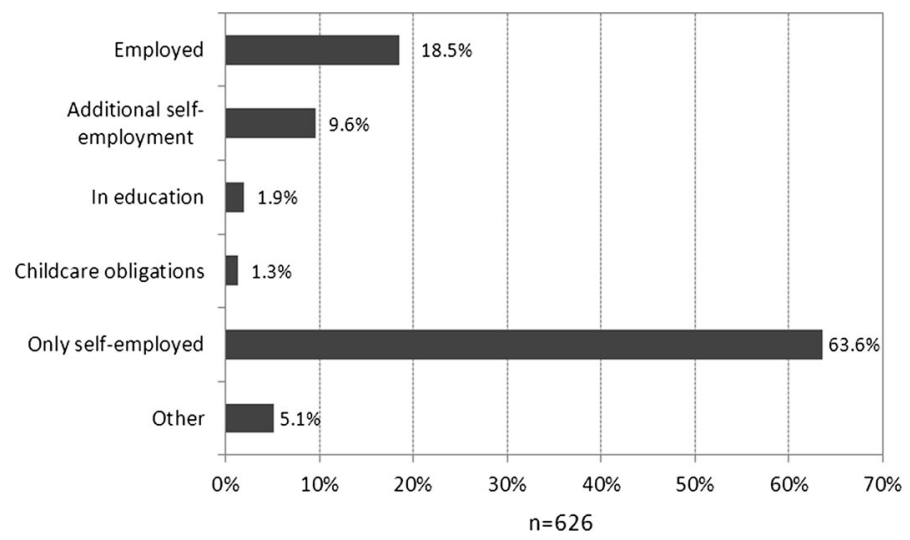

Fig. 4 Self-employment and additional activities (in \%)

order to answer these questions, an econometric model that is explained in the following section has been estimated.

\subsection{Empirical results}

In the following, the determinants of hybrid self-employment are explained by means of an econometric model. The methodological basis for this purpose is a socalled Binary Response Model. Binary Response Models belong to the category of Limited Dependent Variable Models and use a binary dependent variable, also referred to as dummy variables. In the present case the dependent variable describes hybridity in self-employment and takes the value $y=1$ in case of an additional dependent employment (=hybrid one-person enterprise), and the value $y=0$ in all other cases (="regular" one-person enterprise; see Eq. 1).

$$
\text { Additional dependent employment }\} \rightarrow y=1
$$

\begin{tabular}{|c|c|}
\hline Only self-employed & \\
\hline Additional self-employment & \\
\hline In education & \}$\rightarrow y=0$ \\
\hline Childcare obligations & \\
\hline Other & \\
\hline
\end{tabular}

Generally, Binary Response Models estimate response probabilities for the occurrence of $y=1$ subject to a range of independent variables. The response probability is given by 


$$
P(y=1 \mid \vec{x})=G\left(\beta_{0}+\beta_{1} x_{1}+\cdots+\beta_{k} x_{k}\right)
$$

where $\vec{x}$ represents the vector of explanatory variables and $G(\cdot)$ a transformation of the linear function $\beta_{0}+\beta_{1} x_{1}+\cdots+\beta_{k} x_{k}$ which ensures that for all real numbers (and combinations of $\mathrm{x}_{1}, \ldots, \mathrm{x}_{\mathrm{k}}$ ) values or probabilities between 0 and 1 will result $(0<G(\cdot)<1)$. Several distribution functions can be used for such a transformation. If the logistic distribution function shown in Eq. (3) is used for $G(\cdot)$ the BRM is called Logit model. The Probit model uses, by contrast, the distribution function of the standard normal distribution (Wooldridge 2000, $530 \mathrm{ff}$ ).

$$
G(z)=\frac{\exp (z)}{1+\exp (z)}
$$

Generally, both transformations, Logit and Probit, provide similar results. For the current application of identifying the main determinants of hybrid self-employment, the Logit transformation has been used. ${ }^{2}$

The parameters of Logit and Probit models are estimated by MaximumLikelihood. Generally, the Maximum Likelihood Estimator (MLE) for $\beta_{j}$ maximizes the Log Likelihood Function. However, the estimated coefficients cannot be calculated directly. Instead, they are determined by an iterative procedure, which provides consistent, asymptotically efficient and normally distributed estimators (Kohler and Kreuter 2006, 285; Wooldridge 2000, 533 ff).

The final econometric model that is shown in Eq. (4) is the result of an iterative estimation procedure and contains a number of explanatory variables that can be divided into socio-demographic characteristics $\left(X_{i}\right)$, occupation-related variables $\left(Y_{j}\right)$, as well as attitudinal values $\left(Z_{k}\right)$. A detailed description of these variables can be found in Table 2 .

$$
y=\beta_{0}+\beta_{i} X_{i}+\beta_{j} Y_{j}+\beta_{k} Z_{k}+\varepsilon
$$

The estimation results of the Logit model are shown in Table 3 . The model is highly significant, as shown by the Wald- $\chi^{2}$-statistics calculated for the entire set of variables and indicating that the included variables have considerable explanatory power. In addition, the measure of Adjusted McFadden Pseudo- $\mathrm{R}^{2}$ amounting to 0.412 is within the range required for a good model fit. ${ }^{3}$ Usually, a Pseudo- $\mathrm{R}^{2}$ between 0.2 and 0.4 is a pretty good model fit and comparable to an OLS adjusted $\mathrm{R}^{2}$ of 0.7 to 0.9 (Bergmann et al. 2004, 9).

A further possibility to assess the quality of the estimated model is to calculate the proportion of correctly classified answers. Usually, the fitted value, i.e. the predicted outcome of an estimated Logit model, is classified as 1, if the model predicts a probability of greater or equal 0.5 . Otherwise a value of zero is assigned. The predicted outcomes can then be compared with the actual outcomes of the

\footnotetext{
${ }^{2}$ Usually, Probit coefficients must be multiplied by a factor of 1.8 in order to be comparable with the coefficients estimated by Logit.

${ }^{3}$ The interpretation of a Pseudo- $\mathrm{R}^{2}$, which is strictly between 0 and 1 , is somewhat difficult as compared to the standard $\mathrm{R}^{2}$ in a linear regression model. The only thing we can say is that the higher the Pseudo$\mathrm{R}^{2}$, the better the model fit (Kohler and Kreuter 2006, 286).
} 
Table 2 Description of the variables used in the Logit model

Variable and coding

Descriptive statistics

$(\mathrm{n}=626)$

Gender

$1=$ female

$0=$ male

$1=41.8 \%$

Age

Metrically scaled variable

$0=58.2 \%$

Education

Below secondary level (base category)

Secondary school level (1/0)

Tertiary education $(1 / 0)$

Mean $=47.2$ years

Base category $=47.6 \%$

Secondary school level $=25.6 \%$

Tertiary education $=26.8 \%$

Working partner

$$
\begin{aligned}
& 1=\text { Yes } \\
& 0=\text { No }
\end{aligned}
$$

$1=53.7 \%$

$0=46.3 \%$

Start-ups

$1=$ One-person enterprise exists $\leq 1$ year

$1=13.3 \%$

$0=$ One-person enterprise exists $>1$ year

Field of activity

Business and craft (base category)

IT/Consulting (1/0)

Trading sector $(1 / 0)$

$0=86.7 \%$

Other $(1 / 0)$

Self-employment salary

Metrically scaled variable

Business and craft $=37.4 \%$

IT/Consulting $=30.2 \%$

Trading sector $=17.7 \%$

Other $=14.7 \%$

Mean $=€ 1210$

Working hours for one-person enterprise

Metrically scaled variable

Mean $=36.1 \mathrm{~h}$

Start of one-person enterprise

$1=$ Besides dependent employment

$1=22.7 \%$

$0=$ All other possibilities

$0=77.3 \%$

Labour market reasons

$1=$ Start of one-person enterprise due to labour market reasons

$1=25.2 \%$

$0=$ All other motives

$0=74.8 \%$

Regional level

$1=$ One-person enterprise operating at regional level (immediate

$1=81.0 \%$ vicinity and Carinthia)

$0=$ Customers from other regions

$0=19.0 \%$

Combination possibility

$1=$ Combination of self-employment with other activities is regarded as $1=12.5 \%$ an advantage

$0=$ Otherwise

$0=87.5 \%$ 
Table 2 continued

Variable and coding

Descriptive statistics

$(\mathrm{n}=626)$
Uncertain income
$1=$ Uncertain income is regarded as a disadvantage of self-employment
$0=$ Otherwise
$1=64.1 \%$
$0=35.9 \%$

dependent variable. In the final econometric model (shown in Table 3), $90.3 \%$ of the answers can be predicted correctly. Considered separately, 62.9\% of the observations with the characteristic $y=1$ (additional dependent employment) can be correctly specified by the model. This is formally known as "sensitivity". The "specificity" refers to the proportion of correctly specified observations in the group of $y=0$ (no additional employment). Here, the share of correctly classified answers is $96.5 \%$. Translating the values of sensitivity and specificity into a coordinate system yields the so-called "ROC-curve" (Receiver Operating Characteristic). The closer the ROC-curve to the diagonal in the coordinate system, the poorer the model fit. An optimal ROC-curve would correspond to the upper right angle triangle of the coordinate system. This optimal situation would be associated with an area under the ROC-curve of 1. Correspondingly, the closer the calculated area under the ROCcurve is to 1, the better the model fit. The ROC-curve of the final model (see Fig. 5) is relatively close to the optimal right angle triangle of the coordinate system, and, correspondingly, with 0.920 the area under the curve is close to the optimal case of 1 (Fawcett 2003).

Principally, Logit or in the most general sense Binary Response Models are difficult to interpret due to the non-linearity in parameters $\beta_{j}$ imposed by the transformation of the estimation equation. Consequently, the estimated coefficients of a Logit model cannot be interpreted directly. In a first step, it is possible to assess the statistical significance and the sign of the estimated parameters, i.e. the direction of the relationship.

In total, we found nine statistically significant determinants of hybrid selfemployment, i.e. of having an additional dependent employment beside the oneperson enterprise. Age is statistically significant at the $1 \%$ level and affects hybrid self-employment negatively, meaning that older people are less likely to be employed in addition to their activity as a one-person enterprise. This result may reflect the structural problems of elderly people ( $>50$ years) on the (dependent) labour market (Horvath and Mahringer 2014; Klinglmair et al. 2015). Hence, in the age group greater than 50 years, higher unemployment rates are recorded (total unemployment rate: $7.6 \%$, age group $>50$ years: $8.2 \%$ ). In addition, older people are more often affected by long-term unemployment (AMS-Database 2014). For these people, it is therefore harder to find dependent employment that can be exercised in addition to their business activities. Instead, self-employment may represent a possible way out of this precarious labour market situation. Gender-related differences do not exist with regard 
Table 3 Logit model explaining hybrid selfemployment

\begin{tabular}{|c|c|}
\hline Variable & Coefficients \\
\hline Constant $\left(\beta_{0}\right)$ & $\begin{array}{l}0.667 \\
(0.523)\end{array}$ \\
\hline Gender & $\begin{array}{l}0.160 \\
(0.613)\end{array}$ \\
\hline Age & $\begin{array}{l}-0.045^{* * *} \\
(0.004)\end{array}$ \\
\hline \multicolumn{2}{|l|}{ Education } \\
\hline Secondary school level & $\begin{array}{l}-0.434 \\
(0.275)\end{array}$ \\
\hline Tertiary education & $\begin{array}{l}0.598^{*} \\
(0.094)\end{array}$ \\
\hline Working partner & $\begin{array}{l}-0.309 \\
(0.301)\end{array}$ \\
\hline Start-ups & $\begin{array}{l}-1.042 * * \\
(0.020)\end{array}$ \\
\hline \multicolumn{2}{|l|}{ Field of activity } \\
\hline Trading sector & $\begin{array}{l}0.416 \\
(0.338)\end{array}$ \\
\hline IT Consulting & $\begin{array}{l}0.563 \\
(0.162)\end{array}$ \\
\hline Other & $\begin{array}{l}-0.032 \\
(0.945)\end{array}$ \\
\hline Self-employment salary & $\begin{array}{l}-0.001 * * * \\
(0.000)\end{array}$ \\
\hline Working hours for one-person enterprise & $\begin{array}{l}-0.033^{* * *} \\
(0.000)\end{array}$ \\
\hline Start of one-person enterprise & $\begin{array}{l}2.467 * * * \\
(0.000)\end{array}$ \\
\hline Labour market reasons & $\begin{array}{l}-1.392 * * * \\
(0.002)\end{array}$ \\
\hline Regional level & $\begin{array}{l}1.020^{* *} \\
(0.029)\end{array}$ \\
\hline Combination possibility & $\begin{array}{l}2.170 * * * \\
(0.000)\end{array}$ \\
\hline Uncertain income & $\begin{array}{l}0.365 \\
(0.240)\end{array}$ \\
\hline Observations & 626 \\
\hline Wald- $\chi^{2}$-statistic ( $p$ value) & $\begin{array}{l}124.4 \\
(0.000)\end{array}$ \\
\hline Adjusted McFadden Pseudo- $\mathrm{R}^{2}$ & 0.418 \\
\hline
\end{tabular}

$p$ values in parentheses

Significance: $* * * 1 \%$ level ** $5 \%$ level * $10 \%$ level 


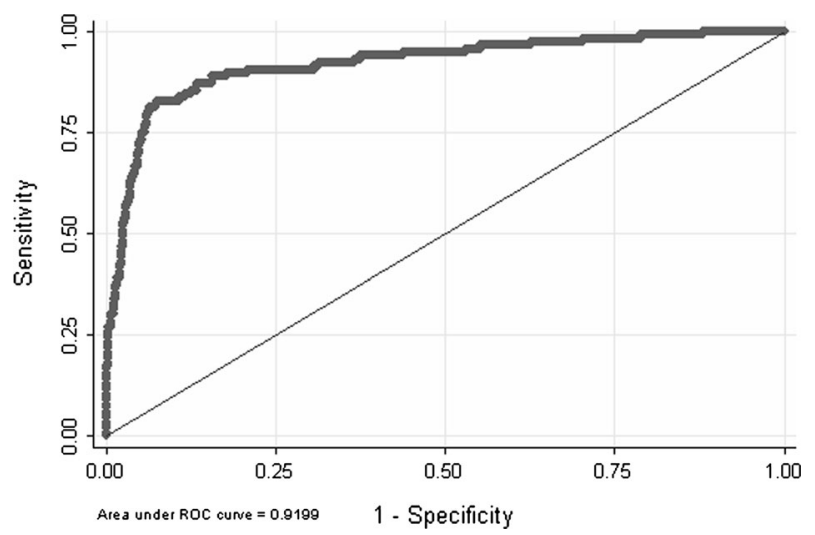

Fig. 5 ROC-curve of the final econometric model

to hybrid self-employment, although existing research indicates that women-as a labour market category-differ concerning their attitudes towards self-employment (Dabic et al. 2012; Dautzenberg 2012; Costin 2012). Furthermore, one-person enterprises where the person has a tertiary education are more likely to be additionally employed compared to their less educated counterparts. This result may also be motivated by the preferable situation of academics on the labour market. In Austria, academics have a significantly lower unemployment rate $(2.7 \%)$ compared to the overall average of $7.6 \%$ (Austria 2014). Moreover, the employment rate of academics amounts to $87.6 \%$ and is considerably higher as compared to the Austrian average of $76.3 \%$ (Statistik Austria 2013a).

Generally, the entry into self-employment may also be determined by family, social and household relations (Bögenhold and Fachinger 2013; Welter 2011). However, the family background does not play a significant role for explaining hybrid self-employment. The existence of a working partner did not show up to be a statistically significant influencing factor. This result may be caused by the fact that the additional dependent employment is in most cases not necessity-driven.

Start-ups are defined as one-person enterprises that exist in the market for less than or equal to 1 year. In the econometric model, start-up one-person enterprises appeared to have a lower probability of holding an additional dependent employment, a result that may arise from the higher time exposure needed in the early stage of the enterprise. The effect is statistically significant at the $5 \%$ level. The field of activity, however, did not show up to be a statistically significant determinant of hybrid self-employment. However, the monthly net income from the business activity and the weekly working hours for self-employment represent significant influencing factors. The higher the income from self-employment and the higher the hours worked per week, the lower the probability of having an additional dependent employment-a logical conclusion.

Beyond that, a very important and highly significant (1\% level) determinant of hybrid self-employment is the situation in which the one-person enterprise was founded. People who started their business activities beside dependent employment 
are also more likely to be additionally employed afterwards. From this, we can conclude that these are the micro enterprises who founded their business as a secondary source of income (side-line business). Furthermore, the motives for being self-employed play a significant role. One-person enterprises that became selfemployed due to labour market reasons (e.g. as an alternative to unemployment) are less likely to hold an additional dependent employment. A logical conclusion, since these one-person enterprises are self-employed only because they were unable to find dependent employment and wanted to escape from unemployment. Finally, micro enterprises operating only at the regional level (clients from the immediate vicinity and Carinthia) and regarding the combination of self-employment with other activities as an advantage exhibit a higher probability of being additionally employed. Income sensitivity, by contrast, has no statistically significant effect on hybrid self-employment.

$$
\text { Odds-Ratio }=\frac{e^{\beta_{0}+\beta_{j}\left(x_{j}+1\right)}}{e^{\beta_{0}+\beta_{j} x_{j}}}=\frac{e^{\beta_{0}+\beta_{j} x_{j}} e^{\beta_{j}}}{e^{\beta_{0}+\beta_{j} x_{j}}}=e^{\beta_{j}}
$$

In order to give the estimated coefficients presented in Table 3 more meaningfulness, Odds-Ratios (exponential coefficients) have been calculated. The Odds-Ratio refers to the chance of having an additional dependent employment $(y=1)$, when $x_{j}$ changes by one unit. Odds-Ratios are calculated according to Eq. (5) (Kohler and Kreuter 2006, 283; Long 1997, 74 ff).

Generally, an Odds-Ratio greater than 1 refers to a higher chance for an occurrence of $y=1$, while Odds-Ratios smaller than 1 point to a lesser chance. ${ }^{4}$ The Odds-Ratios for the final econometric model are given in Table 4. The significance of the estimated coefficients ( $p$ values), as well as measures of model fit such as Pseudo- $\mathrm{R}^{2}$ remained unchanged as compared to Table 3 . The interpretation of the Odds-Ratios is based on a ceteris paribus assumption, that is, all other effects are held constant except for the variable for which the Odds-Ratio is being calculated.

Regarding age, each year reduces the chance of having an additional dependent employment by a factor of approximately $1.05,{ }^{5}$ or, in other words, by $4.5 \%$. Oneperson enterprises with a tertiary education are-ceteris paribus-about twice as likely (Odds-Ratio $=1.82$ ) to be employed beside their business activities than their less educated counterparts. In contrast, one-person start-ups have a 2.8 times (or $64.7 \%$ ) lower chance to hold an additional dependent employment than one-person enterprises existing in the market for longer than 1 year. The more time a oneperson enterprise works for his or her company and the higher the income from selfemployment, the lower the chance of additional dependent employment. Each additional Euro of income from self-employment reduces the chance by a factor of 1.001 (or $0.1 \%$ ). One more working hour for self-employment is associated with a reduced chance of 1.03 (or $3.3 \%$ ). A strong influence on hybrid self-employment is caused by the situation in which the one-person enterprise was founded.

\footnotetext{
${ }^{4}$ As an aside, negative coefficients are associated with Odds-Ratios smaller than 1, positive coefficients with an Odds-Ratio greater than 1.

5 This value results from the inverse of the Odds-Ratio shown in Table 4.
} 
Table 4 Odds-ratios of the estimated Logit model

\begin{tabular}{|c|c|c|}
\hline \multirow{37}{*}{$\begin{array}{l}\text { Table } 4 \text { Odds-ratios of the } \\
\text { estimated Logit model }\end{array}$} & Variable & Odds-ratios \\
\hline & Gender & 1.173 \\
\hline & & $(0.613)$ \\
\hline & Age & $0.955^{* * *}$ \\
\hline & & $(0.004)$ \\
\hline & Education & \\
\hline & Secondary school level & 0.648 \\
\hline & & $(0.275)$ \\
\hline & Tertiary education & $1.819^{*}$ \\
\hline & & $(0.094)$ \\
\hline & Working partner & 0.734 \\
\hline & & $(0.301)$ \\
\hline & Start-ups & $0.353^{* *}$ \\
\hline & & $(0.020)$ \\
\hline & Field of activity & \\
\hline & Trading sector & 1.516 \\
\hline & & $(0.338)$ \\
\hline & IT consulting & 1.756 \\
\hline & & $(0.162)$ \\
\hline & Other & 0.969 \\
\hline & & $(0.945)$ \\
\hline & Self-employment salary & $0.999 * * *$ \\
\hline & & $(0.000)$ \\
\hline & Working hours for one-person enterprise & $0.967 * * *$ \\
\hline & & $(0.000)$ \\
\hline & Start of one-person enterprise & $11.782 * * *$ \\
\hline & & $(0.000)$ \\
\hline & Labour market reasons & $0.249 * * *$ \\
\hline & & $(0.002)$ \\
\hline & Regional level & $2.774 * *$ \\
\hline & & $(0.029)$ \\
\hline & Combination possibility & $8.756 * * *$ \\
\hline & & $(0.000)$ \\
\hline & Uncertain income & 1.440 \\
\hline & & $(0.240)$ \\
\hline & Observations & 626 \\
\hline & Wald- $\chi^{2}$-statistic ( $p$ value $)$ & 124.4 \\
\hline$p$ values in parentheses & & $(0.000)$ \\
\hline Significance: $* * * 1 \%$ level & Adjusted McFadden pseudo- $\mathrm{R}^{2}$ & 0.418 \\
\hline
\end{tabular}

Accordingly, if the micro enterprise started his or her business beside dependent employment, the chance to be dependently employed afterwards is approximately 12 times higher as compared to one-person enterprises that started their business 
activities from another situation (e.g. after a period of unemployment). Hence, oneperson enterprises which started as hybrids, usually remain in the hybrid employment status. Furthermore, a strong and negative effect is given by the motive for self-employment. One-person enterprises that were founded due to economic or labour market reasons have a $75 \%$ (or 4 times) lower chance of exhibiting dependent employment in addition to their business activities than oneperson enterprises with other, non-economic rationalities. Moreover, we found evidence that one-person enterprises operating only at the regional level (with customers from the immediate vicinity or Carinthia) are 2.8 times more likely to be additionally employed than one-person self-employed people that operate nationally and internationally. Finally, respondents regarding the combination options of selfemployment with other activities (e.g. dependent employment) as an advantage are 8.8 times more often dependently employed beside their business activities than one-person enterprises that do not regard this as an advantage.

\section{Conclusions and outlook}

The consideration of the social and economic structure(s) of our modern societies merely as a snapshot of one moment or as a "blueprint" does not acknowledge the dynamics, which are at work behind the balances expressed by the annual figures of labor market data. Stock figures may remain constant, even though there is considerable social mobility taking place in the background, mixing up the individual composition of units. The dualism of continuity and, simultaneously, change and individual regrouping already inspired Joseph A. Schumpeter to write that each social class calls to mind an omnibus or a hotel, which are always fully occupied, but concretely by continuously changing people (Schumpeter 1953). We perceive an increasing relevance of biographical aspects of work, where people switch between wage or salary dependent labor and self-employment-and vice versa-according to job opportunities, age and further individual and societal opportunity costs. Moreover, hybrid forms of employment can be found, when forms of micro entrepreneurship are combined with further activities in dependent labor. Here, we may distinguish between two competing forms of hybridity: We have either those who are self-employed and who have an additional job in dependent work, occasionally and changing or permanently the same, in order to maximize the amount of income, or-vice versa-we find those who are primarily wage or salary dependent workers and who run some form of self-employed activity as freelancer or small(est) business owner as sideline income. Finally, we are familiar with the phenomenon that forms of self-employed activity can be reminiscent of dependent work where entrepreneurial freedom tends towards zero and incomes are sometimes also marginal.

The majority of independent businessmen belong to the category of small economic actors having no further employees in the firms where the owner is his own chief and the only actor. In many countries, they have small and smallest ventures and more than the half of the independent businessmen work without further employees in their companies; they virtually just maintain self-employed 
activities without having a real company building, a registered company name or an entry in the yellow pages. All these forms of economic activity do not match with the regular image of businessmen as "die-hard entrepreneurs" (Burke et al. 2005) having "bigger" firms with multiple employees organized in different levels of hierarchies. If we confront the image with real data, one can see that blurred boundaries with the sector of wage or salary dependent work exist. These blurred boundaries are fluent and dynamic in their nature and they do not fit with ideas of a clean division, which separates the spheres of dependent work strictly from independent work.

The idea of the paper was to deal with the particular case of solo selfemployment as a very specific phenomenon representing the majority of selfemployed activities not only in Europe, but also in Austria. Through an empirical representative study collected in the federal Austrian country Carinthia a survey was conducted based on a questionnaire for one-(wo)man enterprises. Among the diversity of empirical findings, the study found evidence that a quarter of these entrepreneurial activities were created due to labour market reasons. Among the different reasons why people started with self-employment items of a possibility of self-controlled working and an associated higher level of responsibility were reported $(62 \%)$. However, more than $25 \%$ also considered labour market frictions as a pushing factor towards their own self-employed activities.

Having in mind research questions asking about the blurred boundaries between independent and dependent labour, the present research asked for the "non-ideal" forms of self-employment. Less than two-thirds were just regular self-employed, but $10 \%$ practiced more than one form of self-employment and nearly $20 \%$ were additionally engaged in dependent work. Although the area of multiple forms of self-employment must also be considered as a challenging research field, asking if these items reflect a specific form of success or a lack of success so that different activities have to be combined to realize sufficient income, the study asked for factors influencing hybrid forms of employment and status between dependent work and self-employment. It has to be asked whether the additional dependent employment represents a necessity-driven secondary job in order to survive economically, or whether the one-person enterprise represents a secondary source of income. The empirical data indicate that in cases of hybrid self-employment, the one-person enterprises rarely operate as a main business, but instead as a side-line business. Based on econometric modelling, 9 statistically significant determinants of hybrid self-employment were found (see previous chapter for details).

Especially being in a so-called entrepreneurial society (Audretsch 2007) must be explained sociologically. Baumol (1990), Zahra (2006) and Welter (2011) have brought to attention that researchers are faced with a multiplicity of contexts and that one has to distinguish between those institutional variables. Aiming to understand the formation of markets and the inherent competition processes one needs both empirical studies but also a theoretical framework of socio economics helping to investigate seriously social mobility patterns in a wider concept. Research on occupations and labour markets belongs to the issues, which have to be acknowledged in future research (Wiklund et al. 2011). We increasingly find 
ourselves in a society that mirrors a puzzle of labor market patterns and biographical careers in which the clinical dichotomy between wage- or labor-dependent work on the one side and self-employed activities on the other side is muddied. Consequently, also hybrid forms of combinations arise, where people have more than one job at one time, or along the biographical axis of individual careers, so that we observe patterns of multiplicity and parallelisms. Talking about self-employment in the context of social and economic dynamics must deal with the subject not only in the sense of a snapshot, but also from a processual perspective, which includes entrepreneurship as instances of biographical or even episodic processes.

Our study was based upon a genuine empirical survey asking about the rationality of the small entrepreneurs without further employees (including many selfemployed freelancers). What are their economic and social rationalities, and how can they be interpreted in terms of recent popular discussions about selfemployment; is their emergence due to missing chances in the labor market for their stakeholders and/or do they reflect new interesting patterns to interpret and to realize participation in business life? All these aspects contribute to an appropriate understanding of the landscape of one-(wo)man enterprises, while a further research inquiry delves deeper, asking about the socioeconomic logics of these small companies so that research approaches need a multidisciplinary design (Bögenhold et al. 2014).

Acknowledgments Open access funding provided by University of Klagenfurt.

Open Access This article is distributed under the terms of the Creative Commons Attribution 4.0 International License (http://creativecommons.org/licenses/by/4.0/), which permits unrestricted use, distribution, and reproduction in any medium, provided you give appropriate credit to the original author(s) and the source, provide a link to the Creative Commons license, and indicate if changes were made.

\section{References}

Acs ZJ, Karlsson C (2002) Institutions, entrepreneurship and firm growth. Small Bus Econ 19(3):183-290 AMS-Database (2014) Arbeitslosigkeit, Beschäftigung und Arbeitslosenquoten nach Bundesländern. http://iambweb.ams.or.at/ambweb/ Accessed 23 May 2014

Audretsch DB (1995) Innovation and industry evolution. MIT Press, Cambridge

Audretsch DB (2007) The entrepreneurial society. Oxford University Press, Oxford

Austria Bank (2012) Ein-Personen-Unternehmen. Charakteristika, Rahmenbedingungen und der Weg zum Erfolg. UniCredit Bank Austria AG, Vienna

Austria AMS (2014) Arbeitsmarkt \& Bildung - Jahr 2013. AMS-Abteilung ABI, Vienna

Baumol WJ (1990) Entrepreneurship: productive, unproductive, and destructive. J Polit Econ 98:893-922

Bergmann A, Hanley N, Wright R (2004) Valuing the attributes of renewable energy investments. Applied environmental economics conference 2004, University, Glasgow

Bögenhold D (2004) Entrepreneurship: multiple meanings and consequences. Int J Entrep Innov Manag 4(1):3-10

Bögenhold D, Fachinger U (2007) Micro-firms and the margins of entrepreneurship: the restructuring of the labour market. Int J Entrep Innov 8:281-293

Bögenhold D, Fachinger U (2011) Entrepreneurial Diversity: Theoretische und empirische Beleuchtungen der Heterogenität beruflicher Selbständigkeit in Deutschland. Zeitschrift für KMU und Entrepreneurship (ZfKE) 59(4):251-272 
Bögenhold D, Fachinger U (2013) Rationality of self-employment: do female and male entrepreneurs differ? J Bus Finance 1(2):42-62

Bögenhold D, Klinglmair A (2014) Motive für die Tätigkeit als Ein-Personen-Unternehmen in Kärnten. Wirtschaftspolitische Blätter-Sonderausgabe 3-24

Bögenhold D, Klinglmair A (2015) Micro-entrepreneurship: tendency towards precarious work? empirical findings for austria. Athens J Econ Bus 1(2):107-121

Bögenhold D, Heinonen J, Akola L (2014a) Entrepreneurship and independent professionals: social and economic logics. Int Adv Econ Res 20(3):295-310

Bögenhold D, Fink M, Kraus S (2014b) Integrative entrepreneurship research-bridging the gap between sociological and economic perspectives. Int J Entrep Vent 6:118-139

Burke AE, Fitz Roy FR, Nolan MA (2005) What makes a Die-Hard Entrepreneur? Trying, or Persisting in Self-employment. Discussion Papers on Entrepreneurship, Growth, and Public Policy. Max-Plank Foundation, Jena

Castells M (1998) The information age: economy, society and culture, vol 3. Blackwell, Cambridge

Costin Y (2012) In pursuit of growth: an insight into the experience of female entrepreneurs. Int J Gender Entrep 4(2):108-127

Dabic M, Daim T, Bayraktaroglu E, Novak I, Basic M (2012) Exploring gender differences in attitudes of university students towards entrepreneurship: an international survey. Int $\mathbf{J}$ Gender Entrep 4(3):316-336

Dautzenberg K (2012) Gender differences of business owners in technology-based firms. Int J Gender Entrep 4(1):79-98

Davidsson P (1995) Culture, structure and regional levels of entrepreneurship. Entrep Reg Dev 7(1):41-62

Davidsson P (2003) The domain of entrepreneurship research: Some suggestions. In: Katz J, Shepherd D (eds) Advances in entrepreneurship, firm emergence and growth, vol 6. Elsevier, Oxford, pp 315-398

Ehrenberg RG, Smith RS (2003) Modern labor economics. Theory and public policy, 8th edn. Addison Wesley, Boston

Eurostat-Database (2015a) Selbständigkeit nach Geschlecht, Alter und Beruf (lfsa_esgais). http://ec. europa.eu/eurostat/data/database. Accessed 28 September 2015

Eurostat-Database (2015b) Beschäftigung nach Geschlecht, Alter und Stellung im Beruf und Beruf (lfsa_esgais). http://ec.europa.eu/eurostat/data/database. Accessed 28 September 2015

Fawcett T (2003) ROC Graphs: Notes and Practical Considerations for Data Mining Researchers. HP Labs Tech Report, No. HPL-2003-4. Paolo Alto

Folta T, Delmar F, Wennberg K (2010) Hybrid entrepreneurship. Manage Sci 56:253-269

Gatterer H, Kühmayer F (2010) EPU machen Zukunft. Trenddossier zur Zukunft von Ein-PersonenUnternehmen. Zukunftsinstitut Österreich GmbH, Vienna

Horvath T, Mahringer H (2014) Entwicklung der Erwerbsbeteiligung bis 2030 unter Berücksichtigung von Änderungen im Bildungsverhalten und rezenten Pensionsreformen. WIFO Working Papers No. 470, WIFO - Österreichisches Institut für Wirtschaftsforschung, Vienna

Hytti U (2005) New meanings for entrepreneurs: From risk-taking heroes to safe-seeking professionals. J Organiz Change Manag, Special Issue: Change in the Feminine: Women in Change 18, No. 6:594-611

Kalleberg AL (2011) Good Jobs, Bad Jobs. The rise of polarized employment systems in the United States. Basic Books, New York

Klinglmair R, Klinglmair A, Angerer S, Friedl B (2015) Arbeitsmarkt, Bildung und Demographie. Institut für Höhere Studien und Wissenschaftliche Forschung Kärnten (ed.): Bericht zur Wirtschaftslage des Landes Kärnten 2014/15. Gegenwärtige Herausforderungen und künftige Perspektiven. IHSK, Klagenfurt

Kohler U, Kreuter F (2006) Datenanalyse mit Stata. Oldenburg, Munich

Korunka C, Kessler A, Frank H (2011) Lueger M (2011) Conditions for growth in one-person-startups: a longitudinal study spanning eight years. Psicothema 23(3):446-452

Leicht R (2000) Die ‘neuen Selbständigen’ arbeiten alleine. Wachstum und Struktur der Soloselbständigen in Deutschland. Internationales Gewerbearchiv 48:75-90

Long SJ (1997) Regression models for categorical and limited dependent variables, 1st edn. Sage Publications, London

Mandl I, Dörflinger C, Gavac K, Hölzl K, Kremser S, Pecher I (2007) Ein-Personen-Unternehmen in Österreich. Endbericht, KMU Forschung Austria, Vienna 
Mandl I, Gavac K, Hölzl K (2009) Ein-Personen-Unternehmen in Österreich. Wirtschaft und Gesellschaft 35 Jahrgang (2009). Heft 2:215-236

Mueller SL, Thomas AS (2000) Culture and entrepreneurial potential: a nine country study of control and innovativeness. J Bus Ventur 16(1):51-75

Noseleit F (2014) Female self-employment and children. Small Bus Econ 43(3):549-569

Puchleitner K (2014) Chef allein zu Haus: Das Leben als Ein-Personen-Unternehmen. Format (13 February 2014)

Raffiee J, Fen J (2014) Should I quit my job? A hybrid path to entrepreneurship. Acad Manag J 57(4):936-963

Rosner S, Krenn D (2013) Klein, aber hart umkämpft. Wiener Zeitung (20 August 2013)

Schumpeter JA (1953) Die sozialen Klassen im ethnisch homogenen Milieu (orig. 1927). Schumpeter JA (ed.). Aufsätze zur Soziologie, Tübingen, Mohr:147-213

Schumpeter JA (1954) History of economic analysis. Allen \& Unwin, London

Schumpeter JA (1963) The theory of economic development. University Press, Oxford, New York

Shane S (2008) The illusions of entrepreneurship. Yale University Press, New Haven

Shane S, Venkataraman V (2000) The promise of entrepreneurship as a field of research. Acad Manag Rev 25(1):217-226

Statistik Austria (2013a) Arbeitsmarktstatistiken - Ergebnisse der Mikrozensus Arbeitskräfteerhebung und der Offenen-Stellen-Erhebung. Detailergebnisse auf CD-Rom. Verlag Österreich, Vienna

Statistik Austria (2013b) Census 2011 Arbeitsstättenzählung, Ergebnisse zu Arbeitsstätten aus der Registerzählung. Statistik Austria, Vienna

Statistik Austria (2013c) Ergebnisse im Überblick: Statistik zur Unternehmensdemografie 2004 bis 2011, Untergliederung nach Beschäftigungsgrößenklasse. Statistik Austria, Vienna

Statistik Austria (2013d) Tabellenband EU-SILC 2012, Einkommen, Armut und Lebensbedingungen. Statistik Austria, Vienna

Statistik Austria (2014) Statistisches Jahrbuch 2014. Statistik Austria, Vienna

Statistik Austria (2016) Statistisches Jahrbuch 2016. Statistik Austria, Vienna

Thurik R, Dejardin M (2012) Entrepreneurship and culture. In: Gelderen M, Masurel E (eds) Entrepreneurship in Context. Routledge, London, pp 175-186

Welter F (2011) Contextualizing entrepreneurship_conceptual challenges and ways forward. Entrep Theory Practise 35:165-184

Wennekers ARM, van Stel AJ, Carree MA, Thurik AR (2010) The relation between entrepreneurship and economic development: is it U-shaped? Found Trends Entrep 6(3):167-237

Wiklund J, Davidsson P, Audretsch DB, Karlsson C (2011) The Future of Entrepreneurship Research. Entrep Theory Practice 35(1):1-9

WKO - Wirtschaftskammer Österreich (2015) Ein-Personen-Unternehmen (EPU) 2014. EPU-Anteil nach Sparten (Mehrfachmitgliedschaften) (EinzelunternehmerInnen, GmbH). WKO, Vienna

Wooldridge JM (2000) Introductory econometrics. A modern approach. South Western College Publishing, Cincinnati

Zahra SA (2006) Contextualizing theory building in entrepreneurship research. J Bus Ventur 22(3):443-452 